\title{
Selection of low impact concrete mixtures based on life-cycle assessment mixtures
}

\section{Contribuição da avaliação de ciclo de vida na seleção de misturas de concreto de menor impacto ambiental}
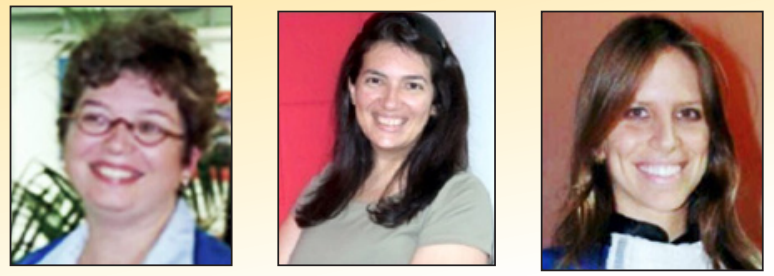

M. G. SILVA

margomes.silva@gmail.com

V. GOMES a

vangomes@gmail.com

M. R. M. SAADE b marcellarms@hotmail.com

\begin{abstract}
Over the past decades, extensive research has been carried out to reduce the environmental impacts associated with the cement and concrete production. Life-cycle assessment (LCA) enables the quantification of the environmental loads and offers a useful perspective to scientifically support such studies. In this paper, we demonstrate LCA's contribution to the selection of low environmental impact concretes, using breakwater coreloc components as a case study. A detailed experimental study was designed for the selection of an alkali activator for blast furnace slag (bfs) to produce concrete suitable for breakwater structures; for the evaluation of concrete properties and for the performance assessment of full scale elements in the field, as well as in the laboratory. Sodium silicate-activated bfs concrete mixtures achieved the best results in terms of performance requirements. Our cradle-to-gate life-cycle assessments showed that, though this chemical activator indeed produces lower global warming potential mixtures than the reference portland CP V-ARI concrete, it induces relevant impacts in several environmental categories. Such information is critical when selecting and optimizing low-impact concrete mixture design, and would not be detected in typical experimental studies that are exclusively guided by compliance with performance requirements.
\end{abstract}

Keywords: life cycle assessment, breakwaters, alkali activated binders, blast furnace slag.

\section{Resumo}

Ao longo das últimas décadas, inúmeras pesquisas vêm sendo desenvolvidas com o objetivo de reduzir os impactos ambientais da produção de cimentos e concretos. Por auxiliar na quantificação das cargas ambientais, a técnica de avaliação de ciclo de vida (ACV) oferecem uma perspectiva particularmente útil a tais estudos. Neste artigo, demonstra-se a contribuição da ACV na seleção de concretos de menor impacto ambiental, utilizando componentes para contenção de ondas marinhas (tipo coreloc) como estudo de caso. Um programa experimental teve como objetivo selecionar um ativador alcalino para escória de alto-forno adequado ao processo de produção, avaliar propriedades de corpos-de-prova de concreto e o desempenho de componentes em escala natural, em campo e em laboratório. A ativação da escória de alto-forno por silicato de sódio alcançou os melhores resultados para os critérios de desempenho selecionados. Entretanto, as avaliações de ciclo de vida do 'berço ao portão' demonstraram que, apesar de realmente reduzir o potencial de aquecimento global em relação ao concreto com CP V-ARI, o emprego deste ativador traz impactos relevantes em várias categorias ambientais. Estas são informações cruciais para seleção e otimização da dosagem de concretos de menor impacto ambiental, e não seriam detectadas em estudos experimentais exclusivamente orientados a desempenho.

Palavras-chave: avaliação de ciclo de vida, componentes para contenção de ondas, ligantes álcali-ativado, escória de alto-forno. 


\section{Introduction}

Portland cement contributes with 74 to $81 \%$ of concrete $\mathrm{CO}_{2}$ emissions [1]. On its turn, portland clinker is responsible for approximately $90 \%$ of cement's $\mathrm{CO}_{2}$ emissions, due to limestone decarbonation and intensive fossil fuel use in the kiln [2][3].

A number of research efforts has focused on reducing the cement environmental impact, prioritizing development of reduced clinker content cements; alternative raw materials to replace limestone in the kiln feed; alternative fuels mixtures and enhanced thermal efficiency of the kiln system and carbon capture technologies [4][5]. In 2015, UN Program "Sustainable Building and Climate Initiative" created a task group to explore feasible alternative technologies to reduce $\mathrm{CO}_{2}$ emissions and to increase efficiency along cement's value chain, with particular focus on materials solutions [6]. The study concluded that in the next 20 to 30 years, two approaches can contribute to significantly reduce cement and concrete production and use-related emissions: increased proportion of minera admixtures as partial clinker replacement in portland cement; and more efficient use of clinker in mortars and concretes [6]. Those authors understand that, at least in the near future, portland cement will continue to dominate the market, due to scale economy, optimized production process, raw material availability and confidence in this traditional product.

Development of the Brazilian Cement Technology Roadmap by the local industry also began in 2015, following the strategies and guidelines Global Cement Roadmap [4] and of CSI/WBCSD [7]. This initiative, coordinated by the Brazilian Association of Portland Cement (ABCP) and by the National Cement Industry Union (SNIC), mapped national cement industry's current $\mathrm{CO}_{2}$ emissions, as well as the main alternatives for reducing them in the future (2050). A strategic vision on mineral admixtures and other clinker substitutes identified potential challenges and opportunities to be considered in action emission mitigation plans, considering a potential increase in cement production [2].

Fly ash, ground granulated blast furnace slag (bfs), and silica fume are among the aluminosilicates included in the wide variety of waste materials used as supplementary cementitious materials (SCMs), at partial clinker replacement in portland cement manufacture [2]. Limestone filler and calcinated clay are other mineral admixtures that, as ternary mixtures with clinker, are pointed out as alternatives for reduced $\mathrm{CO}_{2}$ emission within the cement and concrete production chain in a scenario of limited availability of waste mineral admixtures [6]. These authors also suggest that limestone filler content may be increased by a combination of particle dimension control and water reducer admixture, resulting in cement with reduced water demand [6].

In early 2018, the Brazilian Association for Technical Standardization (ABNT) reactivated the committee CE-018:100.001, aiming to revise national standards on portland cement specification. One of the discussions follows the trend of the ongoing revision of the European standard EN197-1: 2011 [8], and addresses increased mineral admixture content in cement.

Use of binary, ternary or even quaternary mixtures produced from the combination of different mineral admixtures and portland clinker [5][6] are the subject of many research studies. The development of silico-aluminates binders, - such as fly ash, bfs or metakaolin, that are activated by alkaline hydroxide, carbonate or silicate solutions [9][10] have been the focus of researchers worldwide. Scrivener et al. (2016) [6] argue that the contribution of such binders to $\mathrm{CO}_{2}$ emission mitigation depends, first, on the availability of the material to be activated - like fly ash, calcined clay and bfs, whose use as portland cement (mineral admixture) replacement is much simpler - and, on the other hand, on technologies that produce less cost-, energy- and emission-intensive alkaline activators.

The first studies on alkali activated binders and concretes were conducted by Kuhl's in the 30's, when the setting time of ground bfs in $\mathrm{KOH}$ solution were evaluated. Subsequent research studies carried out in the 40's by Purdon, and in the 60's by Glukhovsky, are also important references. Efforts in alkali-activated blast furnace slag (AAbfs) binders progressed significantly in the 80 's and 90 's [9]. Particularly motivated by environmental concerns, research interest on AAbfs grew exponentially after 2000, due to the potential to combine several high mechanical strength and compliance with durability requirements to reduced energy consumption and greenhouse gas (GHG) emissions [10][11].

The competitiveness of these binders, in terms of environmental impact, became, therefore, essential to support further research. Life cycle assessment (LCA) is guided by ISO standards 14040:2006 [14] and 14044:2006 [15] and was consolidated over the past decade. It now stands out as a valuable addition to laboratory and field tests, for offering the most appropriate platform for comparing environmental impacts of concretes and binder systems [16].

This research background motivated a series of R\&D projects to strategically explore possibilities to add value to steelmaking coproducts, particularly bfs. Among those initiatives, the development of 'coreloc' breakwater structures began in 2002. A detailed experimental study was designed to select an alkaline activator for bfs concrete adequate to this application, and to assess physical, mechanical and durability properties, based on laboratory tests of specimens produced with AAbfs binders. Full size scale components were also monitored in the field and in laboratory environment [12][13].

This paper demonstrates how life cycle assessment can complement the traditional performance-oriented approach and provide essential environmental information for selecting low impact concrete mixtures.

\section{Materials and methods}

A theoretical and detailed experimental approach was established to optimize the 'coreloc' breakwater structure and concrete design. A triple framework analysis was adopted. The first analysis stage focused on suitability of the alkali-activator/binder system(s) and corresponding concrete mixture to proceed towards detailed investigation. The second stage covered the performance assessment of components immersed in seawater in the field and at laboratory, tested at different ages. Finally, the third analysis stage comprised 'cradle-to-gate' life cycle assessments, which limit the system boundaries to the production of the concrete mixtures compliant with breakwater structure application and corresponding components, in accordance with ISO 14044:2006 [15].

The use of this technique relies upon a number of critical methodological choices regarding, for example, system boundaries, 


\section{Table 1}

Physical properties of portland cements CP III-40 RS and CP V-ARI, and of binder with 50\% CP III-40 RS and $50 \%$ ground bfs

\begin{tabular}{|c|c|c|c|c|}
\hline \multicolumn{2}{|c|}{ Tests } & CPIII-40 RS' & $\begin{array}{c}50 \% \text { CPIII- } 40^{1} \text { RS + 50\% } \\
\text { ground bfs }\end{array}$ & CP V-ARI ${ }^{2}$ \\
\hline \multicolumn{2}{|c|}{ Fineness - Residue in sieve \#0,075 mm (\%) } & 0.6 & 0.4 & 0.01 \\
\hline \multirow{2}{*}{ Setting time } & Beginning (h:min.) & $2: 50$ & $2: 30$ & $2: 00$ \\
\hline & End (h:min.) & $4: 20$ & $4: 30$ & $2: 25$ \\
\hline Autoclave expansion & warm $(\mathrm{mm})$ & 0 & 1 & 0 \\
\hline \multicolumn{2}{|c|}{ Specific gravity $\left(\mathrm{kg} / \mathrm{m}^{3}\right)$} & 2,986 & 2.94 & 3.09 \\
\hline \multicolumn{2}{|c|}{ Blaine fineness, specific surface $\left(\mathrm{cm}^{2} / \mathrm{g}\right)$} & 4,220 & 4,150 & 4,817 \\
\hline \multirow{4}{*}{$\begin{array}{l}\text { Compressive strength } \\
\text { (MPa) }\end{array}$} & 1 day & - & - & 26.0 \\
\hline & 3 days & 16.9 & 14.2 & 39.8 \\
\hline & 7 days & 31.7 & 23.4 & 43.8 \\
\hline & 28 days & 49.5 & 42.8 & 50.6 \\
\hline
\end{tabular}

Source: ${ }^{\text {the authors } \text { and }}{ }^{2}$ the manufacturer

functional units, characterization factors, (allocation) methods to solve multifunctionality problems, and selection of impact assessment methods and background (i.e. generic data)/foreground (i.e. specifically collected for the study) data sources.

Few authors have quantified the environmental impact of alkaliactivated binders [17][18][19][20][21]. Among those who used lifecycle assessment, most of them performed 'cradle-to- gate' studies [16]. As to the functional unit, Habert and Ouellet-Plamondon [16] concluded that concretes with similar paste content provide a more appropriate basis for comparison and characterize the functional equivalence required for comparative LCAs. These two methodological decisions were also adopted in the present study.

\subsection{Materials used}

The binders used in this study were produced by activating granu-

\section{Table 2}

Chemical composition of Portland cement CP III-40 RS

\begin{tabular}{cc}
\hline Chemical composition & Amount (\%) \\
\hline Silicon dioxide $\left(\mathrm{SiO}_{2}\right)$ & 29.88 \\
Aluminum oxide $\left(\mathrm{Al}_{2} \mathrm{O}_{3}\right)$ & 9.92 \\
Ferric oxide $\left(\mathrm{Fe}_{2} \mathrm{O}_{3}\right)$ & 1.43 \\
Total calcium oxide $(\mathrm{CaO})$ & 50.95 \\
Magnesium oxide $(\mathrm{MgO})$ & 5.78 \\
Sulfur trioxide $\left(\mathrm{SO}_{3}\right)$ & 0.69 \\
Sodium oxide $\left(\mathrm{Na}_{2} \mathrm{O}\right)$ & 0.09 \\
Potassium oxide $\left(\mathrm{K}_{2} \mathrm{O}\right)$ & 0.36 \\
Sulfur $(\mathrm{S})$ & 0.62 \\
Anhydrocarbon $\left(\mathrm{CO}_{2}\right)$ & 0.15 \\
Free calcium oxide $(\mathrm{CaO})$ & 2.30 \\
Titanium oxide $\left(\mathrm{TiO}_{2}\right)$ & 0.38 \\
Insoluble residue & 0.35 \\
Loss on ignition & 0.32 \\
Equivalent alkalies $\mathrm{Na}_{2} \mathrm{O}$ & 0.33 \\
(0,658 x $\left.\mathrm{K}_{2} \mathrm{O} \%+\mathrm{Na}_{2} \mathrm{O} \%\right)$ &
\end{tabular}

Source: the authors lated bfs with clinker (from portland cement CP III-40 RS (bfs content about $70 \%$ ), hydrated lime $\mathrm{CH}$ I, sodium silicate (silica module of 1,62 and solids content of $47,78 \%$ ) and gypsum (fineness < $0,075 \mathrm{~mm})$. Glass content and refractive index of the basic granulated bfs were $96 \%$ and 1,65, respectively. Chemical composition and physical characteristics of granulated bfs used in the alkali-activated binding systems are compatible with published literature and Brazilian standards. The granulated bfs also had physical characteristics compatible with literature and Brazilian standards for fine aggregates, however presenting angular shape. Coarse bfs, obtained by slow cooling, was used as coarse aggregate, slowly cooled and ground to suit specifications for coarse aggregate sizes B1

\section{Table 3}

Main chemical characteristics of Portland cement CP V-ARI

\begin{tabular}{cc}
\hline Chemical composition & Amount (\%) \\
\hline Sulfur trioxide $\left(\mathrm{SO}_{3}\right)$ & 2.87 \\
Free calcium oxide $(\mathrm{CaO})$ & 1.20 \\
Insoluble residue & 0.46 \\
Loss on ignition & 3.80 \\
\hline
\end{tabular}

Source: the manufacturer

\section{Table 4}

Chemical composition of ground granulated blast furnace slag

\begin{tabular}{cc}
\hline Chemical composition & Content (\%) \\
\hline Silicon dioxide $\left(\mathrm{SiO}_{2}\right)$ & 33.02 \\
Aluminum oxide $\left(\mathrm{Al}_{2} \mathrm{O}_{3}\right)$ & 12.64 \\
Ferric oxide $\left(\mathrm{Fe}_{2} \mathrm{O}_{3}\right)$ & 0.68 \\
Calcium oxide $(\mathrm{CaO})$ & 42.83 \\
Magnesium oxide $(\mathrm{MgO})$ & 7.71 \\
Sulfur $(\mathrm{S})$ & 1.06 \\
Sodium oxide $\left(\mathrm{Na}_{2} \mathrm{O}\right)$ & 0.17 \\
Potassium oxide $\left(\mathrm{K}_{2} \mathrm{O}\right)$ & 0.31 \\
Titanium oxide $\left(\mathrm{TiO}_{2}\right)$ & 0.60 \\
\hline
\end{tabular}

Source: the authors 


\section{Table 5}

Chemical composition and physical characteristics of ground granulated blast furnace slag

\begin{tabular}{cc}
\hline Chemical composition & Content (\%) \\
\hline Silicon dioxide $\left(\mathrm{SiO}_{2}\right)$ & 33.02 \\
Aluminum oxide $\left(\mathrm{Al}_{2} \mathrm{O}_{3}\right)$ & 12.64 \\
Ferric oxide $\left(\mathrm{Fe}_{2} \mathrm{O}_{3}\right)$ & 0.68 \\
Calcium oxide $(\mathrm{CaO})$ & 42.83 \\
Magnesium oxide $(\mathrm{MgO})$ & 7.71 \\
Sulfur $(\mathrm{S})$ & 1.06 \\
Sodium oxide $\left(\mathrm{Na}_{2} \mathrm{O}\right)$ & 0.17 \\
Potassium oxide $\left(\mathrm{K}_{2} \mathrm{O}\right)$ & 0.31 \\
Titanium oxide $\left(\mathrm{TiO}_{2}\right)$ & 0.60 \\
Fineness by \#. $325(\%)$ & 0.4 \\
Blaine fineness, specific surface $\left(\mathrm{cm}^{2} / \mathrm{g}\right)$ & 4.100 \\
Specific gravity $\left(\mathrm{kg} / \mathrm{m}^{3}\right)$ & 2.906 \\
\hline
\end{tabular}

Source: the authors

(9,5-19 mm) and B2 (19-25 mm). Table 1 to Table 12 and Figure 1 to Figure 4 show characterization of materials used.

Table 13 presents the mixture proportions of all AAbfs concrete modelled for life cycle assessment (LCA). For comparison purposes, concrete mixtures with natural aggregates and portland cements (CP V-ARI and CP III-40 RS) were experimentally designed (Table 14) and corresponding LCAs carried out. Cement CP V-ARI ( $90 \%$ clinker, $6 \%$ limestone filler) has the most similar composition to OPC (ordinary Portland cement) and allows for comparison with international publications; whilst Cement CP III-40 RS ( 24\% clinker, $70 \%$ bfs and $1,8 \%$ limestone filler) is the alternative with the lowest clinker content allowed in Brazil, and also the most used cement type in the geographic region where the study was carried out. All cements were produced in the same plant, from the same clinker and mineral admixtures.

Mixture design followed the American Concrete Institute (ACl) method and aimed to reach compressive strength compatible with breakwaters structures, established as 46,6 MPa at 28 days (40 MPa-fck, with a $4 \mathrm{MPa}$-standard deviation). Paste content (27\%), mortar content (58\%), water/powder ratio $(9,4 \%)$, water/ binder ratio $(0,45)$ and mixture proportions, in unit mass of binder (1: $1,04: 0,62: 0,93: 0,45$; binder : fine aggregate : coarse aggregate (B1) : coarse aggregate (B2): water; in mass), were kept constant to ensure LCA results were comparable, as recommended [16] to provide functional equivalency in LCAs. Mix-

\section{Table 6}

Glass content, refraction index and physical characteristics of granulated blast furnace slag

\begin{tabular}{cc}
\hline Test & Results \\
\hline Glass content (\%) & 96 \\
Refraction index & 1.65 \\
Nature & Alkaline \\
Fineness modulus & 2.94 \\
Maximum nominal size & $2.4 \mathrm{~mm}$ \\
Specific gravity & $2.80 \mathrm{~kg} / \mathrm{dm}^{3}$ \\
Unit weight & $1.28 \mathrm{~kg} / \mathrm{dm}^{3}$ \\
Material finer than $75 \mu \mathrm{m}$ & $0.18 \%$ \\
Clay content (lumps and friable particles) & $0.1 \%$ \\
\hline Source: the authors
\end{tabular}

Table 7

Physical characteristics of sand

\begin{tabular}{cc}
\hline Physical characteristics & \\
\hline Maximum characteristic dimension & $2.4 \mathrm{~mm}$ \\
Fineness modulus & 2.56 \\
Material finer than $75 \mu \mathrm{m}$ & $0.14 \%$ \\
Clay content (lumps and friable particles) & $0.00 \%$ \\
Organic impurities & Clearer \\
Specific gravity & $2.65 \mathrm{~kg} / \mathrm{dm}^{3}$ \\
Unit weight & $1.43 \mathrm{~kg} / \mathrm{dm}^{3}$ \\
\hline
\end{tabular}

Source: the authors

ing water was corrected to consider the sodium silicate's solids content $(47,78 \%)$ whenever used, and maintain water/binder ratio constant in all mixtures.

\subsection{Breakwater structure design}

Geometry definition for the breakwater structures considered ease of production and compliance with bending and torsion internal tensions calculated through finite element method [22]. The Coreloc geometry that provided the lowest internal tensions is presented in Figure 5. The element dimensions were obtained through Hudson Equation [Equation 1, [23].

$W=\frac{w_{r} \cdot H^{3}}{K_{d \cdot}\left(S_{r}-1\right)^{3} \cdot \cot g(\alpha)}$

\section{Table 8}

Physical characteristics of coarse blast furnace slag B1 and B2

\begin{tabular}{|c|c|c|}
\hline Characteristic & Coarse bfs B1 & Coarse bfs B2 \\
\hline Maximum nominal size & $19 \mathrm{~mm}$ & $32 \mathrm{~mm}$ \\
\hline Fineness modulus & 6,98 & 7,20 \\
\hline Specific gravity & $2,56 \mathrm{~kg} / \mathrm{dm}^{3}$ & $2,55 \mathrm{~kg} / \mathrm{dm}^{3}$ \\
\hline Unit weight & $1,32 \mathrm{~kg} / \mathrm{dm}^{3}$ & $1,24 \mathrm{~kg} / \mathrm{dm}^{3}$ \\
\hline Material finer than $75 \mu \mathrm{m}$ & $1,54 \%$ & $1,28 \%$ \\
\hline Clay content (lumps and friable particles) & $1,55 \%$ & $1,28 \%$ \\
\hline Los Angeles abrasion, $40 \% \mathrm{~B} 1$ and $60 \% \mathrm{~B} 2$ & $28 \%$ & $28 \%$ \\
\hline
\end{tabular}

Source: the authors 
Where:

$\mathrm{W}$ is the block's design mass;

$\mathrm{w}_{\mathrm{r}}$ is the block's unit weight (adopted as $2300 \mathrm{~kg} / \mathrm{m}^{3}$, as in [23]);

\section{Table 9}

Physical characteristics of gravel \# 1 and \# 2

\begin{tabular}{cc}
\hline Chemical composition & Content (\%) \\
\hline Maximum nominal size & $19.0 \mathrm{~mm}$ \\
Fineness modulus & 6.93 \\
Material finer than $75 \mu \mathrm{m}$ & $0.43 \%$ \\
Clay content (lumps and friable particles) & $0.16 \%$ \\
Specific gravity & $2.77 \mathrm{~kg} / \mathrm{dm}^{3}$ \\
Absorption & $0.50 \%$ \\
Unit weight & $1.47 \mathrm{~kg} / \mathrm{dm}^{3}$ \\
Dry rodded unit weight & - \\
40\% gravel \# 1 + 60\% gravel \# 2 & $1.60 \mathrm{~kg} / \mathrm{dm}^{3}$ \\
Los Angeles abrasion, 40\% gravel \# 1+60\% & $38 \%$ \\
gravel \# 2 &
\end{tabular}

Table 10

Chemical composition and physical characteristics of hydrated lime $\mathrm{CH}$ I

\begin{tabular}{cc}
\hline Chemical composition & Amount (\%) \\
\hline Silicon dioxide $\left(\mathrm{SiO}_{2}\right)$ & 0.93 \\
Aluminum oxide $\left(\mathrm{Al}_{2} \mathrm{O}_{3}\right)$ & 0.27 \\
Ferric oxide $\left(\mathrm{Fe}_{2} \mathrm{O}_{3}\right)$ & 0.36 \\
Calcium oxide $(\mathrm{CaO})$ & 72.48 \\
Anhydrous sulfuric $\mathrm{acid}\left(\mathrm{SO}_{3}\right)$ & 0.14 \\
Sodium oxide $\left(\mathrm{Na}_{2} \mathrm{O}\right)$ & - \\
Potassium oxide $\left(\mathrm{K}_{2} \mathrm{O}\right)$ & 0.07 \\
Loss on ignition & 25.28 \\
Material retained in sieve \# 30 (g) & 0 \\
Material retained in sieve \# 200 (g) & 0.37 \\
Specific gravity $\left(\mathrm{kg} / \mathrm{dm}^{3}\right)$ & 2.32 \\
\hline
\end{tabular}

Source: the authors

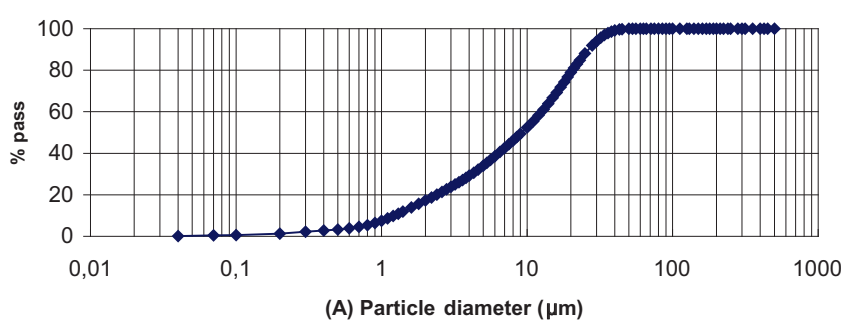

$\mathrm{H}$ is the design wave height at the toe of the structure;

$\mathrm{K}_{\mathrm{d}}$ is a dimensionless stability coefficient (adopted as 13, as in [23]);

$S_{r}$ is the ratio between the densities of the block's material and that of (sea)water; and

$\alpha$ is the angle of revetment with the horizontal.

\section{Table 11}

Chemical composition and specific gravity of gypsum

\begin{tabular}{cc}
\hline Chemical composition & Amount (\%) \\
\hline Silicon dioxide $\left(\mathrm{SiO}_{2}\right)$ & 5.36 \\
Aluminum oxide $\left(\mathrm{Al}_{2} \mathrm{O}_{3}\right)$ & 0.47 \\
Ferric oxide $\left(\mathrm{Fe}_{2} \mathrm{O}_{3}\right)$ & 0.38 \\
Calcium oxide $(\mathrm{CaO})$ & 37.55 \\
Anhydrous sulfuric acid $\left(\mathrm{SO}_{3}\right)$ & 47.30 \\
Sodium oxide $\left(\mathrm{Na}_{2} \mathrm{O}\right)$ & 0.05 \\
Potassium oxide $\left(\mathrm{K}_{2} \mathrm{O}\right)$ & 0.26 \\
Loss on ignition & 8.85 \\
Specific gravity $\left(\mathrm{kg} / \mathrm{dm}^{3}\right)$ & 2.64 \\
\hline
\end{tabular}

Source: the authors

\section{Table 12}

Physical and chemical characteristics of sodium silicate

\begin{tabular}{cc}
\hline Analyzed item & Results \\
\hline $\mathrm{Na}_{2} \mathrm{O}(\%)$ & 18,196 \\
$\mathrm{SiO}_{2}(\%)$ & 29,584 \\
Total solids & 47,780 \\
Moisture & 52,220 \\
Silica ratio $\left(\mathrm{SiO}_{2} / \mathrm{Na}_{2} \mathrm{O}\right)$ & 1.62 \\
Density at $25^{\circ} \mathrm{C}(\mathrm{g} / \mathrm{l})$ & 1,605 \\
Viscosity at $25^{\circ} \mathrm{C}(\mathrm{CP})$ & 830 \\
Degrees ${ }^{\circ} \mathrm{Be}$ & 54.5 \\
\hline Source: the manufacturer
\end{tabular}

Source: the manufacture

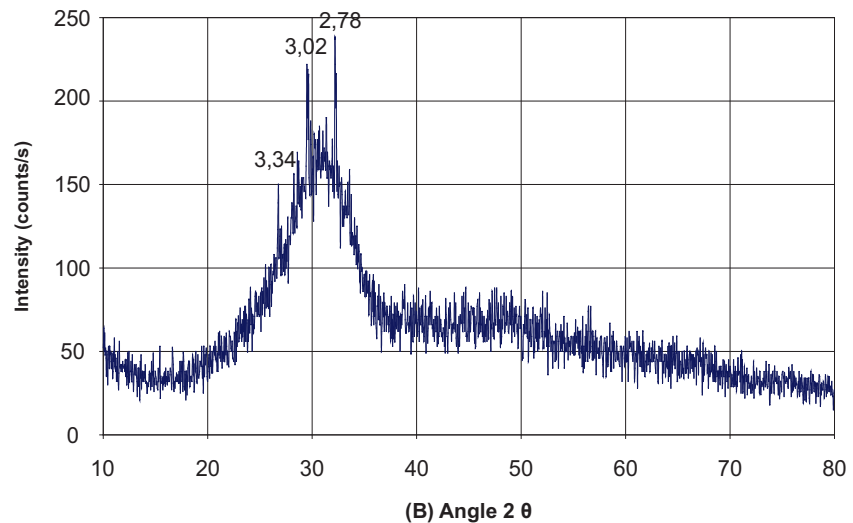

\section{Figure 1}

Particle size distribution and (B) X-ray diffraction of ground granulated bfs

Source: the authors 


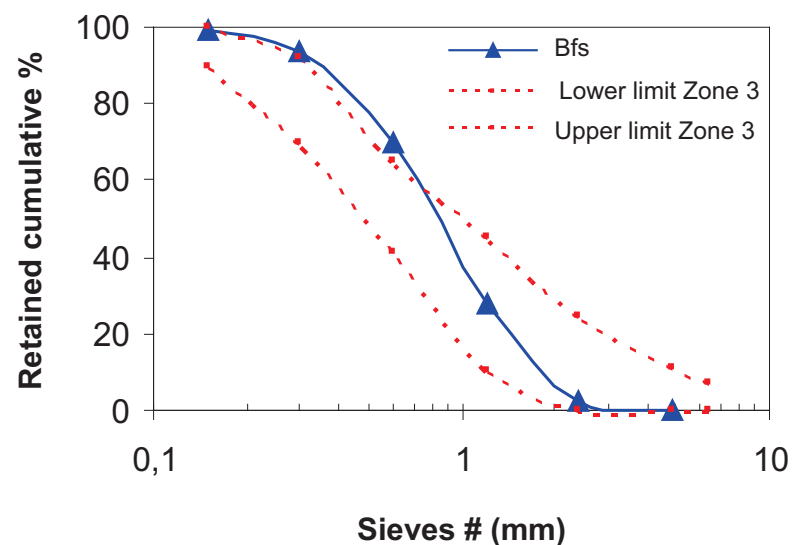

(A)

Figure 2

Sieve analysis of (A) granulated bfs and (B) sands Source: the authors

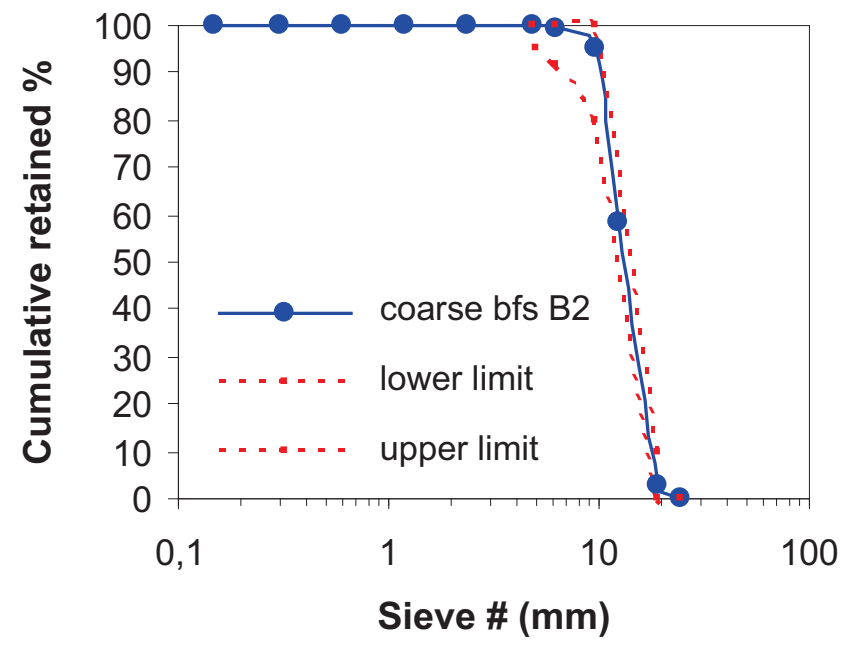

Figure 3

Sieve analysis of coarse bfs B1 and B2

Source: the authors

\subsection{Properties' assessment of concretes with alkali-activated blast furnace slag (AAbfs) binder systems}

Previous studies assessed workability (slump test), air content, unit weight of fresh concretes with AAbfs binder systems, as well as corresponding test specimens regarding compressive strength (at 7 and 28 days); splitting tensile strength and compressive strength, unit weight, water absorption, voids content, capillary water absorption and modulus of elasticity (at 28 days), shrinkage (at 365 days), and resistance to sulfate attack and chloride ions penetration [12][13].

Ten full size breakwater elements produced with the selected mixture were exposed to marine environment for one year for durability assessment (Figure 6a, Figure 7). Cores were then extracted from the blocks and tested in laboratory for compressive strength, unit weight, water absorption, voids content and chloride ions diffusion. In parallel, sets of specimens and one full-sized breakwater were immersed for one year in a laboratory seawater-filled tidal

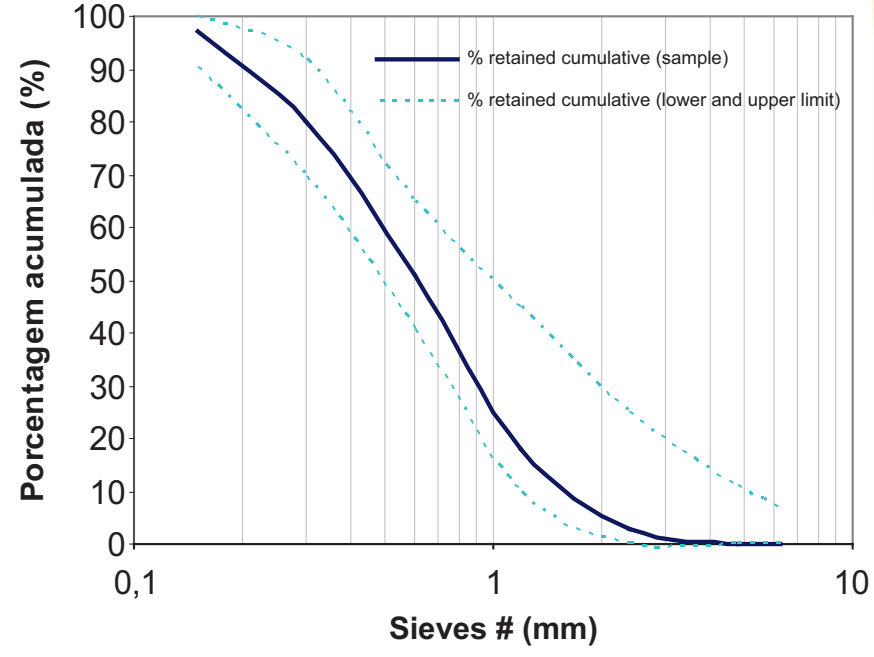

(B)
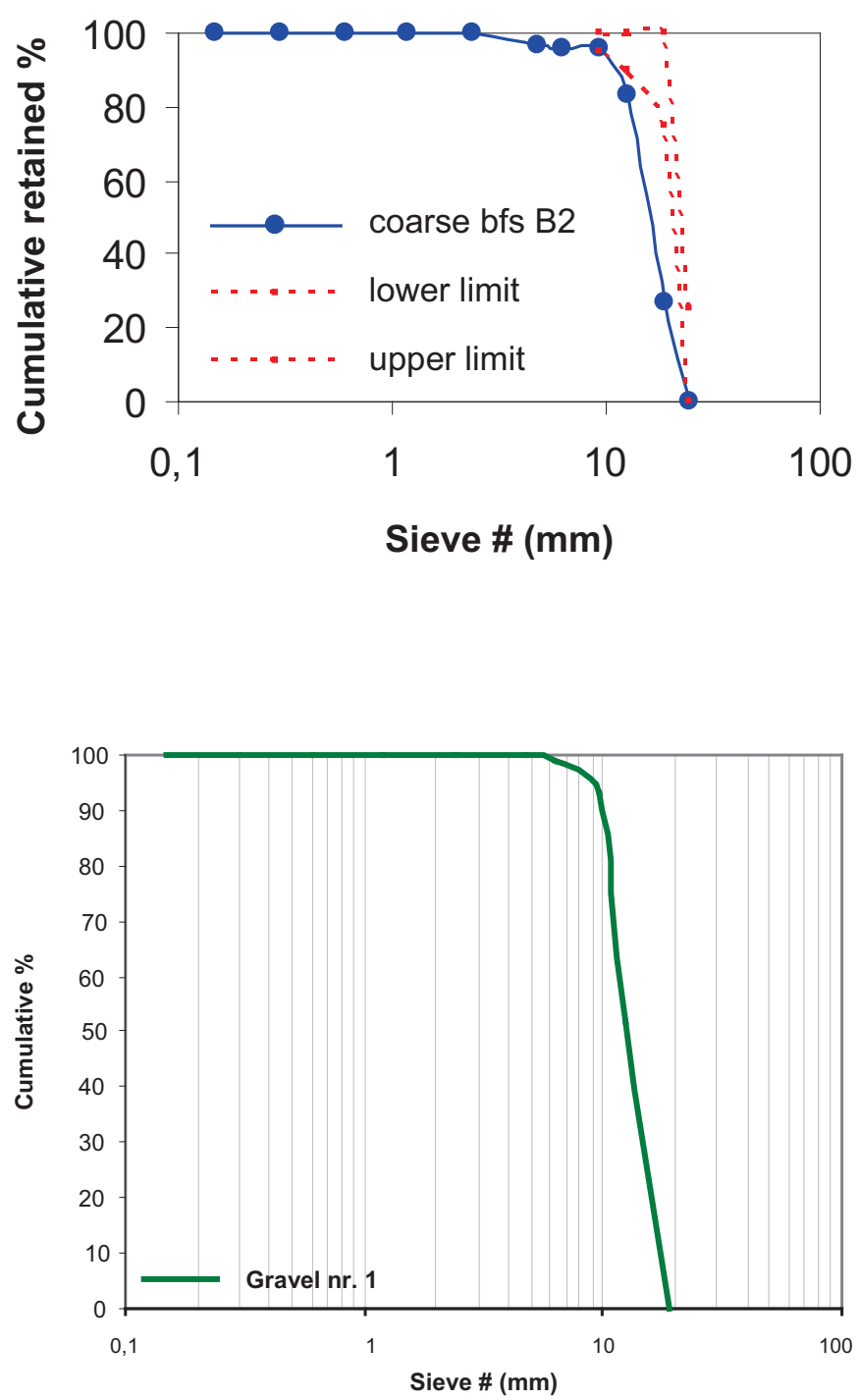

\section{Figure 4}

Sieve analysis of natural gravel $\mathrm{nr} .1$

Source: the authors 
Table 13

Materials used in AAbfs concretes, in $\mathrm{kg}$, for LCA modelling

\begin{tabular}{|c|c|c|c|c|c|c|c|c|c|}
\hline \multirow{2}{*}{ Mixture } & \multirow{2}{*}{$\begin{array}{c}\text { CP III-40 } \\
\text { RS }\end{array}$} & \multirow{2}{*}{$\begin{array}{c}\text { Ground } \\
\text { granulated } \\
\text { bfs }\end{array}$} & \multirow{2}{*}{ Lime } & \multirow{2}{*}{$\begin{array}{l}\text { Sodium } \\
\text { silicate }\end{array}$} & \multirow{2}{*}{ Gypsum } & \multirow{2}{*}{$\begin{array}{c}\text { Granulated } \\
\text { bfs* }\end{array}$} & \multicolumn{2}{|c|}{ Coarse bfs** } & \multirow{2}{*}{ Water } \\
\hline & & & & & & & B1 & B2 & \\
\hline$A$ & 20.00 & 20.00 & - & - & - & 41.76 & 24.76 & 37.00 & 18.00 \\
\hline B & 9.41 & 27.39 & 3.20 & _- & _- & 41.76 & 24.76 & 37.00 & 18.00 \\
\hline C & 9.41 & 26.59 & 4.00 & - & - & 41.76 & 24.76 & 37.00 & 18.00 \\
\hline D3 & - & 31.41 & 2.00 & 6.59 & - & 41.76 & 24.76 & 37.00 & 14.55 \\
\hline D4 & - & 28.58 & 2.00 & 9.42 & - & 41.76 & 24.76 & 37.00 & 13.08 \\
\hline D5 & - & 27.01 & 2.00 & 10.99 & - & 41.76 & 24.76 & 37.00 & 12.26 \\
\hline E & _ & 36.80 & 0.80 & - & 2.40 & 41.76 & 24.76 & 37.00 & 18.00 \\
\hline
\end{tabular}

\section{Table 14}

Materials used in Portland cement concretes, in kg, for LCA modelling

\begin{tabular}{ccccccc}
\hline Mix & CP III-32 RS & CP V-ARI & Sand & Gravel B1 & Gravel B2 & Water \\
\hline CP III-32 & 40.00 & - & 41.76 & 24.76 & 37.00 & 18.00 \\
CP V-ARI & - & 40.00 & 41.76 & 24.76 & 37.00 & 18.00 \\
\hline
\end{tabular}
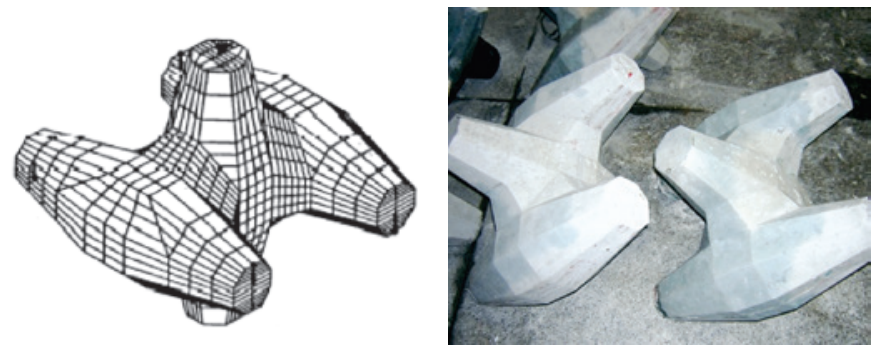

Figure 5

Coreloc breakwater structure geometry

Source: the authors

movement simulator (Figure 6b), and kept in wet chamber (Figure $6 \mathrm{c}$ ), and subjected to the same mechanical and physical tests. Parametric hypothesis tests ANOVA and Duncan were used to determine significant statistical differences (at $5 \%$ significance level) of those properties' average results.

\subsection{Lifecycle assessment (LCA) of concretes}

'Cradle to gate' LCAs were carried out for each concrete mixture compliant with standardized or predefined performance requirements for breakwater application, observing ISO 14040: 2006 [14] guidelines and using SimaPro 7.3 specialist software [24]. The functional unit defined for comparison of concretes was "one unit of characteristic compressive strength ( $1 \mathrm{MPa})$ ". Table 15 shows the data sources used in production cycle modelling. Whenever local data were unavailable, Ecoinvent database v.2.2 was used upon the original energy grid by the Brazilian matrix.

Current limitations to regionalize Ecoinvent v3 data and impact assessment methods contained in varied versions of SimaPro platform challenge direct comparison with recent results published by authors like [16]. We then opted for using SimaPro v.7.3, CML baseline 2001 v.2.05 life cycle impact assessment method and our adapted version of Ecoinvent v.2.2 to assess Brazilian processes, as in previous studies [25][26].
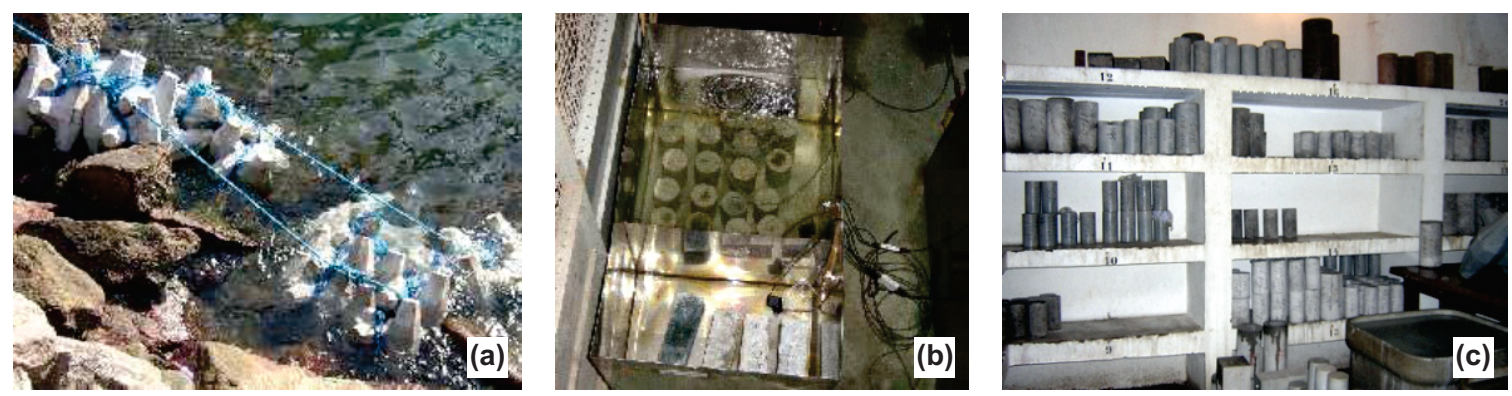

\section{Figure 6}

(a) Breakwater structures exposed to marine environment; (b) specimens in seawater-filled tidal movement simulator; (c) specimens stored in wet chamber

Source: the authors 


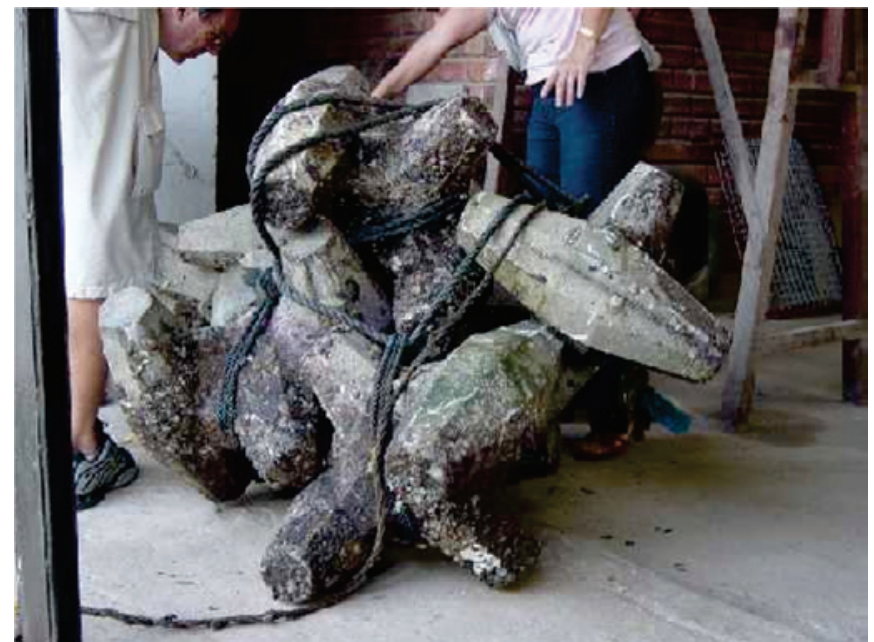

Figure 7

Breakwater structures after one year of exposure to marine environment

Source: the authors

Once the productive processes were modelled and respective inventories obtained for each concrete mixture, the following impact indicators were calculated per functional unit: (i) renewable energy $\left(E_{\text {ren }}\right)$ and (ii) non-renewable energy $\left(E_{\text {nren }}\right)$; (iii) global warming potential (GWP); (iv) acidification potential (AP); (v) eutrophication potential (EP); (vi) photochemical ozone creation potential (POCP); (vii) ozone layer depletion potential (ODP); (viii) blue water footprint (bWF); and (ix) non-renewable raw material consumption (NRC). The first seven indicators compose the minimum environmental impact categories structure for environmental product declarations (EPD) defined by EN 15804: 2012 [27].

Renewable and non-renewable energy indicators inform about the use of energy resources over the lifecycle of a product and enlighten potential savings ranking. GWP indicates greenhouse gas emissions over the lifecycle and is relevant in carbon-intensive processes, such as clinker manufacture. Acidification and eutrophication potential indicators describe direct effects on ecosystems. Acidification - caused by acid substances or substances that combined with elements naturally present in the atmosphere, become acid - impacts soil, air and water quality, and attack built structures. On its turn, eutrophication is a phenomenon caused by macronutrients excess in the environment, caused by emissions of (primarily) organic matter into air, water and soil. Potential for photochemical ozone creation (POCP) measures potential levels of tropospheric ozone formation, a toxic reactive substance for humans and ecosystems. Ozone depletion potential (ODP) measures emissions of different chlorofluorocarbon gases (or similar) that contribute to ozone layer depletion, which in turn allows higher UV-B radiation to reach the Earth's surface, affecting human, animal, terrestrial and aquatic ecosystems. These indicators are used in most LCA studies [28] and mandatory in environmental product declarations (EPD) of construction materials and products.

The last two indicators - blue water footprint and non-renewable raw material - are direct measures of, respectively, potable water and abiotic elements inputs identified in the product's life cycle inventory. Both indicators highlight natural resources depletion potential of the studied activity. Though scarcely documented in EPDs, they report relevant use information for construction materials in general, and for concrete in particular. Considering indicators that add insight beyond typical GHG emissions in LCAs of concrete allows that other relevant environmental impacts are also controlled in the quest for 'carbon-efficient' alternatives, avoiding that environmental burdens are shifted.

Blue water footprint (bWF) was calculated as proposed by [29], and computed surface and underground water inputs directly from the inventory [Equation 2]. Analogously, the calculation of nonrenewable raw material (NRc) per functional unit added mineral non-renewable raw material inputs identified in the product's life cycle inventory [Equation 3].

$b W F=\left(\sum_{i=1}^{n} b W_{i}\right.$ per functional unit $)$

Where:

bWF is the blue water footprint, in $\mathrm{m}^{3} / \mathrm{MPa}$;

$\mathrm{bW}_{\mathrm{i}}$ is the quantity of each (surface or underground) blue water input identified in the product's life cycle inventory;

$\mathrm{n}$ is the number of water source inputs identified in the product's life cycle inventory.

The calculations of primary embodied energy ( $E$, representing all energy resources used, from raw material extraction for concrete manufacture) followed the Cumulative Energy Demand (CED) method, which totals the primary energy inputs over the life cycle of a given product, in $\mathrm{MJ}_{\mathrm{e}}$. The calculations of the renewable and non-renewable energy fractions were made separately [Equation 3].

$E=\left(\sum_{i=1}^{n} E_{i}\right.$ per functional unit $)$

Where:

$\mathrm{E}$ is the primary embodied energy of concrete mixtures, in MJ/MPa, divided into renewable (Eren) and non-renewable (Enren) sources; $E_{i}$ is the (renewable/non-renewable) primary energy input identified in the life cycle inventory;

$\mathrm{n}$ is the number of primary energy inputs identified.

\section{Table 15}

Data sources for modelling production cycles of concretes' constituents

\begin{tabular}{|c|c|}
\hline Material ${ }^{1}$ & Source \\
\hline Blast furnace slag & Steel industry reports ${ }^{2}$ \\
\hline Cement CP III-40 & SILVA, 2006b [34] \\
\hline Gypsum & $\begin{array}{c}\text { SimaPro } 7.3^{3} \text { raw material } \\
\text { database }\end{array}$ \\
\hline \multicolumn{2}{|l|}{ Hydrated lime } \\
\hline \multicolumn{2}{|l|}{ Limestone } \\
\hline \multicolumn{2}{|l|}{ Clinker } \\
\hline Water & Ecoinvent v.2.2 \\
\hline \multicolumn{2}{|l|}{ Sodium silicate } \\
\hline \multicolumn{2}{|l|}{ Sand } \\
\hline \multicolumn{2}{|l|}{ Granite $^{4}$} \\
\hline $\begin{array}{l}{[1] \text { electricity grids in internation }} \\
{[2] \text { steel slags production data } \mathrm{w}} \\
\text { environmental agency; }[3] \text { Simal } \\
\text { any industrial processing; [4] ad } \\
\text { Source: the authors }\end{array}$ & $\begin{array}{l}\text { were altered to the national grid; } \\
\text { ed from reports directed to the local } \\
\text { t-in database for raw material without } \\
\text { Ecoinvent's basaltic gravel. }\end{array}$ \\
\hline
\end{tabular}


Potentials for global warming (GWP), acidification (AP), eutrophication (EP), photochemical ozone creation (POCP) and ozone layer depletion (ODP) were obtained through CML baseline 2001 v.2.05. GWP, expressed in mass of carbon dioxide-equivalent per functional unit $\left(\mathrm{CO}_{2 \mathrm{e}} \mathrm{MPa}\right)$, was therefore calculated by multiplying the mass of greenhouse gases (GHG) emitted by corresponding emission factors [Equation 4].

$G W P=\left(\sum_{i=1}^{n} G W P_{i} \times m_{i}\right.$ per functional unit $)$

Where:

GWP represents the global warming potential, in $\mathrm{kg}$ of $\mathrm{CO}_{2 \mathrm{e}} / \mathrm{MPa}$; $\mathrm{GWP}_{\mathrm{i}}$ is the $\mathrm{CO}_{2 \mathrm{e}}$-equivalence factor for each greenhouse gas (GHG) considered by CML 2001 v.2.05;

$m_{i}$ is the mass of each corresponding GHG emission;

$\mathrm{n}$ is the number of $\mathrm{GHG}$ considered.

Analogously, ODP (expressed in $\mathrm{kg}$ of $\mathrm{CFC}$-11-equivalent/MPa), $\mathrm{AP}$ (expressed in $\mathrm{kg}$ of $\mathrm{SO}_{2}$-equivalent/MPa), EP (expressed in $\mathrm{kg}$ of $\mathrm{PO}_{4}$-equivalent/MPa), and POCP (expressed in $\mathrm{kg}$ of ethyleneequivalent, $\mathrm{C}_{2} \mathrm{H}_{4}$-equivalent/MPa) were calculated by multiplying the potential impact equivalency factor of each substance considered by CML 2001 v.2.05, in each category, by their respective mass.

In order to solve multifunctional problems intrinsic to concretes made from alkali-activated coproduct binders [30], we refined calculations of the traditional avoided impact approach, commonly used in multifunctional process LCA [31]. The net avoided burden approach [17] [18] considers the balance of the loads generated and avoided by the co-product use and distributes it based on the initial problem avoided by each industry involved. In this way, the impact avoided by the steel industry refers to bfs end-of-life loads, while the impact avoided by the cement industry refers to the waiving of clinker production, which in turn is replaced by bfs. In addition, we performed a sensitivity analysis considering allocation [15] as impact distribution method, based on the mass and economic value of pig iron and blast furnace slag.

\section{Results and discussion}

\subsection{Compressive strength and workability of Portland cement concretes}

Table 16 shows slump test and compressive strength results (7 and 28 days) of Portland concrete specimens. Variance analysis (5\% significance) shows no significant difference regarding compressive strength (28 days) of concretes with CP III-40 RS and CP V-ARI cements. The Duncan test (5\% significance) also identified a homogeneous group, represented by the compressive strengths at 28 days of concrete with the two Portland cements. Achieved compressive strengths meet the design fck adopted in the breakwater structure design.

\subsection{Alkali activator and AAbfs concrete screening}

Table 17 summarizes slump test and compressive strength results, at 7 and 28 days of age, of concrete specimens with AAbfs binders. Concretes produced with bfs activated by clinker (Mix A), clinker + lime (Mix B and Mix C), lime + gypsum (Mix E) and 3\% $\mathrm{Na}_{2} \mathrm{O}$-sodium silicate (Mix D3) were discarded for not meeting the components' design compressive strength.

\section{Table 16}

Workability (slump test) and compressive strength of portland cement concretes.

The variance analysis ( $5 \%$ significance) shows no significant difference between the averages.

The Duncan test ( $5 \%$ significance) identified a homogeneous group (CP III + CP V)

\begin{tabular}{ccccc}
\hline \multirow{2}{*}{ Mixture } & \multirow{2}{*}{ Binder } & \multirow{2}{*}{ Slump test (mm) } & \multicolumn{3}{c}{ Compressive strength (MPa) } \\
& & & 7 days & 28 days \\
\hline CP III & Portland cement CP III-40 RS & 100 & 40.35 & 48.47 \\
CPV & Portland cement CP V-ARI & 110 & 43.06 & 50.16 \\
\hline
\end{tabular}

Source: the authors

\section{Table 17}

Workability (slump test) and compressive strength of concretes with alkali-activated blast furnace slag (AAbfs). The variance analysis (5\% significance) shows significant difference between the averages. The Duncan test ( $5 \%$ significance) identified five homogeneous groups (E; D3; B+C; A e D4+D5)

\begin{tabular}{ccccc}
\hline \multirow{2}{*}{ Mixture } & Activator & \multirow{2}{*}{ Slump test $(\mathbf{m m})$} & \multicolumn{2}{c}{ Compressive strength $(\mathrm{MPa})$} \\
$\mathbf{7}$ days & 28 days \\
\hline A & Portland clinker & 110 & 28.5 & 36.1 \\
B & Portland clinker + limestone & 50 & 18.0 & 25.1 \\
C & Portland clinker + limestone & 70 & 17.6 & 24.8 \\
D3 & Sodium silicate, $3 \% \mathrm{Na}_{2} \mathrm{O}$ & 190 & 17.6 & 22.1 \\
D4 & Sodium silicate, $4 \% \mathrm{Na}_{2} \mathrm{O}$ & 70 & 41.4 & 48.4 \\
D5 & Sodium silicate, $5 \% \mathrm{Na}_{2} \mathrm{O}$ & 150 & 46.8 & 49.7 \\
E & limestone + gypsum & 30 & 13.0 & 16.2 \\
\hline
\end{tabular}

Source: the authors 
Table 18

Concrete properties of Mix D4

\begin{tabular}{cc}
\hline Properties & Mix D4 \\
\hline Slump $(\mathrm{mm})$ & 220 \\
Air content $\%$ ) & 2.2 \\
Unit weight in fresh state $\left(\mathrm{kg} / \mathrm{m}^{3}\right)$ & 2274 \\
Compressive strength (7 days) (MPa) & 42.5 \\
Compressive strength (28 days) (MPa) & 48.4 \\
Flexural strength (28 days) (MPa) & 5.52 \\
Splitting tensile strength (28 days) (MPa) & 3.60 \\
Unit weight (28 days) ( $\left./ \mathrm{cm}^{3}\right)$ & 2.48 \\
Absorption (28 days) (\%) & 6.93 \\
Voids content (28 days) (\%) & 14.64 \\
Capillary absorption (28 days) (g/cm²) & 2.20 \\
Modulus of elasticity (0.3 $\mathrm{f}_{\mathrm{c}}$ ) (28 dias) (GPa) & 28.71 \\
Sulfate attack (\%) - sulfate solution & 0.011 \\
Sulfate attack (\%) - limestone solution & 0.02 \\
Flexural strength (90 days) (MPa) - & 6.42 \\
sulfate solution & 7.34 \\
Flexural strength (90 days) (MPa) - & 0.093 \\
limestone solution & 941 (very low) \\
Shrinkage (365 days) (\%) &
\end{tabular}

Source: the authors

Concretes produced with bfs activated by sodium silicate with 4\% (Mix D4) and $5 \%$ (Mix D5) of $\mathrm{Na}_{2} \mathrm{O}$ met the design compressive strength. Mix D4 was selected to proceed in the evaluations for presenting adequate compressive strength at the lowest activator content.

\subsection{Properties of selected AAbfs concrete (Mix D4)}

Table 18 presents results of properties of fresh mixture D4 (slump test, air content and unit weight), as well as results of compressive strength ( 7 and 28 days of age); flexural strength and splitting tensile strength; unit weight, water absorption, voids content, capillary water absorption and modulus of elasticity (28 days of age); drying shrinkage ( 365 days of age); and of resistance to sulfate attack and to chloride ions penetration of specimens made with the same mixture.

Table 19 shows the results of compressive strength, splitting tensile strength, unit weight, water absorption, voids content, and chloride diffusion of specimens immersed in seawater tanks, which simulated tidal movement, and of test specimens of Mix D4 maintained in wet chamber environment. It also shows results for cores extracted from the D4 component after one year in the marine environment. All mixtures produced in different batches had their compressive strengths and slump test results recorded. It is noteworthy the difference in slump of D4 mixtures produced on different days (Table 17 and Table 18), in a laboratory that does not possess environmental control. Some researchers mention that the mixing intensity itself can result in friction-induced temperature increase, with acceleration of setting, hardening and change in workability [32].

Table 17, Table 18 and Table 19 make evident that Mix D4 is suitable for breakwater application, offering components with high mechanical strength, reduced chloride diffusion, high resistance

\section{Table 19}

Properties of mixture D4 specimens subjected to two exposure conditions: in sea water tanks with tidal movement simulation [1], in wet chamber [2], and of cores extracted from full-size components after a 365-day exposure to marine environment [3]

\begin{tabular}{ccccc}
\hline \multirow{2}{*}{ Properties } & \multicolumn{4}{c}{ Concrete } \\
\cline { 2 - 5 } & $\mathbf{2 8}$ & \multicolumn{3}{c}{ 365 days } \\
\cline { 2 - 5 } & days & {$[\mathbf{1}]$} & {$[\mathbf{2}]$} & {$[\mathbf{3}]$} \\
\hline Compressive strength $(\mathrm{MPa})$ & 48.4 & 54.1 & 50.2 & 51.9 \\
Splitting tensile strength (MPa) & 3.60 & 4.12 & 4.10 & 3.82 \\
Unit weight $\left(\mathrm{g} / \mathrm{cm}^{3}\right)$ & 2,480 & 2,530 & 2,535 & 2,660 \\
Absorption (\%) & 6.93 & 8.02 & 7.92 & 7.21 \\
Voids content (\%) & 14.64 & 16.82 & 16.73 & 16.00 \\
Chloride diffusion (C) & 941 & 653 & 481 & 823 \\
\hline
\end{tabular}

Source: the authors

to sulfate attack, and durability in the marine environment. Proper curing is critical to prevent shrinkage. Mix D4's water absorption is compatible with the porosity observed in concrete with sodium silicate-activated bfs binders. These results corroborate findings presented in other publications [9] [10] [11] [12] [13].

\subsection{Life cycle assessment of concretes}

Figure 8 presents the values obtained for each impact category in relation to concrete with CP V-ARI (vertical axis). Negative bars, to the left of the shaft, indicate higher environmental performance than concrete with CP V-ARI. As expected, the use of CP III-40 RS instead of CP V-ARI in concrete results in considerable reductions in all impact categories, ranging from $54 \%$ (non-renewable raw material consumption) to $150 \%$ (global warming potential). Also as

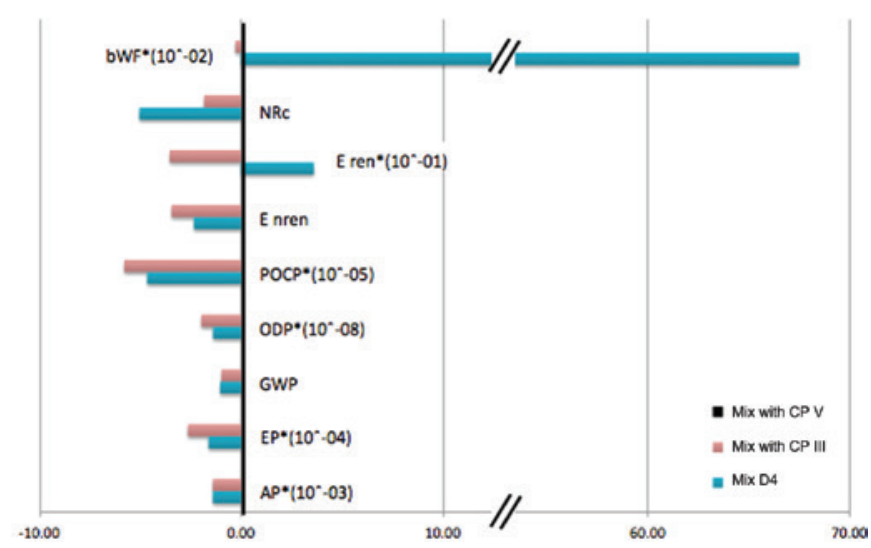

Figure 8

LCA results for Mix D4 and concrete with portland cement CP III-40 RS, relatively to concrete with portland cement CP V-ARI (vertical axis): environmental performance improves towards the left of the vertical axis

Source: the authors 


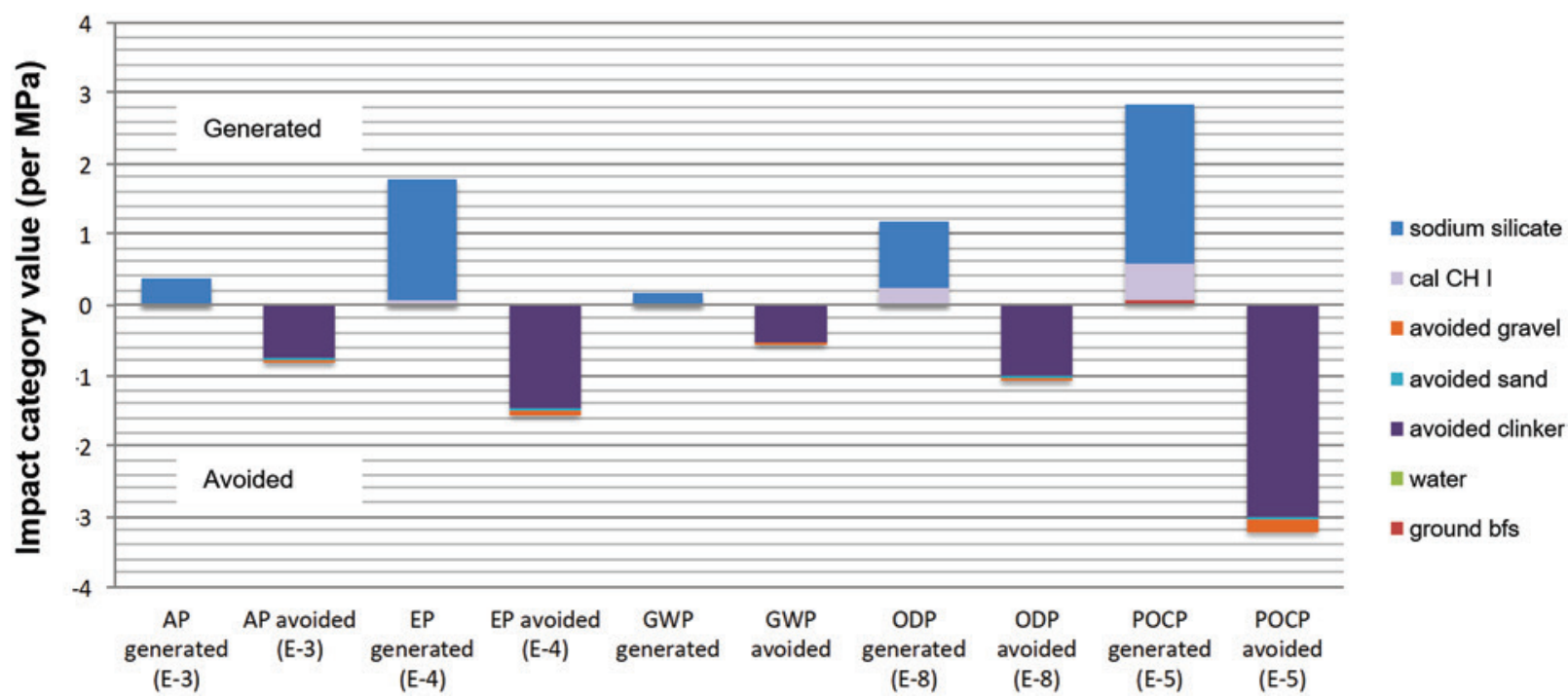

Figure 9

Contribution of Mix D4 constituents to avoided and generated environmental impacts in the categories calculated through method CML baseline 2001 v.2.05

Source: the authors

expected [33], Mix D4 presents significantly superior performance to concrete with CP V-ARI, for all categories but renewable energy and, notably, blue water footprint. These categories are largely influenced by high energy consumption in the production of sodium silicate, and water-intensive bfs granulation.

However, when compared to concrete with CP III-40 RS, the lowest environmental impact cement currently available nationwide, the additional performance improvement brought about by Mix D4 is limited to $\sim 10 \%$ reductions in global warming potential and $\sim 80$ $\%$ in the consumption of non-renewable raw material, while values

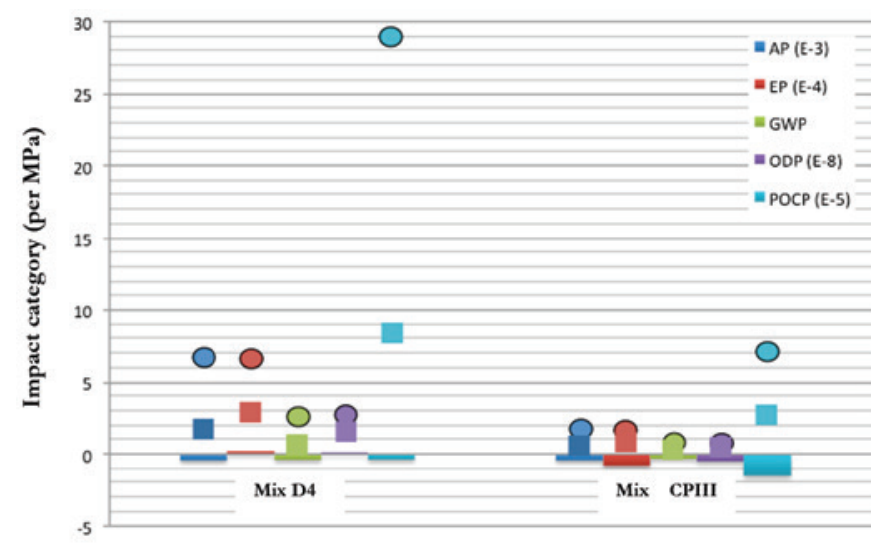

\section{Figure 10}

Results sensitivity (categories calculated through method CML baseline 2001 v.2.05) to the impact distribution criteria: net avoided burden (columns), economic value (squares) and mass (circles) allocation

Source: the authors of all other indicators increase considerably, except for acidification potential, which remains the same.

Figure 9 , on its turn, indicates that the contribution of sodium silicate, although small for global warming potential, is significant for the other impact categories calculated by the CML baseline 2001 v.2.05 method, particularly photochemical oxidation (POCP) and eutrophication (EP) potentials.

In compliance with ISO 14044: 2006 [15], we analyzed results' sensitivity to the variation of impact distribution methods in the modeling of the multifunctional process that generates bfs and other co-products. We analyzed the results of mixtures containing co-products (D4 and CP III) for the impact categories calculated by the CML baseline 2001 v.2.05, considering, in addition to the avoided net impact approach, the allocation according to economic and mass criteria (Figure 10).

Global warming potential - typically emphasized in environmental assessments of concrete - and ozone depletion categories are little sensitive to the impact distribution method. Apart from these two categories, only the photochemical oxidation potential (POCP) varies markedly for concrete with CP III-40 RS ( $28 \mathrm{~kg}$ of bfs in the binder), whereas for Mix D4 ( $133 \mathrm{~kg}$ of bfs as binder and aggregates), all categories are quite sensitive, especially POCP. Despite this variation, Mix D4 presented inferior environmental performance than the concrete with CP III-40 RS. As the search for environmentally superior concretes and cements moves away from clinker-based binders, broadening focus from global warming potential to consider other impact categories becomes more critical.

The concrete mixtures screening process presented here was composed of three stages. Stage 1 identified that only concretes with CP III-40 RS and CP V-ARI portland cements, and sodium silicate-activated bfs mixtures D4 and D5 met the functional performance requirements. Mix D4 (sodium silicate-activated bfs binder, composed by $71.5 \%$ of bfs, $5 \% \mathrm{CH}$ I-lime and $23.5 \%$ sodium sili- 
cate, in mass) used the least amount of activator and hence was used on the second stage of field and laboratory tests. The second stage confirmed compatibility of Mix D4 functional performance with the manufacture of coreloc breakwater structures. Its environmental performance had still to be determined and validated relatively to portland concrete.

In the third stage of analysis, the 'cradle-to-gate' LCAs clearly showed that the use of sodium silicate as a blast furnace slag activator contributes very little to global warming potential. This allows to provide functionally suitable concretes for the application in breakwater components at a 161\% GWP lower than for concretes with CP V-ARI cement ( 90\% clinker, by mass), a slightly better result (10\%) than that obtained for concrete with CP III-40 RS cement ( $24 \%$ clinker, by mass). However, if GWP is excluded from the analysis, sodium silicate used in the binder system only outperforms concrete with CP III-40 RS for non-renewable content (NRc); impacts in various environmental categories are relevant, and increase with increasing silicate content. This situation would not be detected in typical performance-oriented experimental studies. Traditional concrete mixture selection, based solely on global warming potential, would ignore it completely.

\section{Conclusions}

Among the alternatives to reduce the environmental impacts of cements and concretes, especially those related to $\mathrm{CO}_{2}$ emissions, the use of mineral admixtures as clinker replacement and the development of alkali-activated binders have attracted research in various parts of Brazil and the world. However, the contribution of these binders to the mitigation of $\mathrm{CO}_{2}$ emissions depends on the availability of materials to be activated and of production technologies of less cost-, energy- and emission-intensive alkaline activators.

For the application illustrated in this article - breakwater structures - we have shown that, if blast furnace slag is available, it is possible to produce concretes based on alkali-activated binders that meet the performance requirements imposed by the desired application at lower contribution to global warming than the portland cements considered. Moreover, we showed the importance of looking beyond $\mathrm{CO}_{2}$ emissions, since a strategy based on a single environmental impact indicator may create new difficulties, although apparently offering a solution to the original problem.

We propose, therefore, the systematic inclusion of LCA as a methodological step, still at early development of concrete mixtures, to broadly examine implications of the choices made, from a multienvironmental categories viewpoint. Regardless of the mixtures constituents, we demonstrate how LCA complements the traditional performance-oriented approach and supports screening and selection of optimized low-impact mixture designs to advance in the subsequent stages, with significant savings in resources and investigation time.

\section{References}

[1] FLOWER, D. J. M.; SANJAYAN, J. G. Green House Gas Emissions due to Concrete Manufacture. Int. Journal of Life Cycle Assessment. 12 (5) 292-288.

[2] SILVA, M. G.; BATTAGIN, A. F.; GOMES, V. Cimento Port- land com Adições Minerais. In: ISAIA, G. C. (Ed.). Materiais de Construção Civil e Princípios de Ciência e Engenharia de Materiais. 2017.

[3] HUMPHREYS, K.; MAHASENAN, M. Toward a Sustainable Cement Industry, Substudy 8, Climate Change. World Business Council for Sustainable Development. 2002. 34p.

[4] INTERNATIONAL ENERGY AGENCY/WORLD BUSINESS COUNCIL FOR SUSTAINABLE DEVELOPMENT. Cement Technology Roadmap. 2009, 36 p.

[5] DAMTOFT, J.S.; LUKASIK, J.; HERFORT, D.; SORRENTINO, D.; GARTNER, E.M. Sustainable development and climate change initiatives. Cement and Concrete Research 38 (2008) 115-127.

[6] SCRIVENER, K.; JOHN, V. M.; GARTNER, E. M. Eco-efficient cements: Potential, economically viable solutions for a low-CO2, cement based materials industry. United Nations Environment Programme. 2016.

[7] SINDICATO NACIONAL DA INDÚSTRIA DO CIMENTO (SNIC). Relatório Anual, 2014. Disponível em: <snic.org.br/ pdf/RelatorioAnual2014final>.

[8] EUROPEAN COMMITTEE FOR STANDARDIZATION (CEN). EN 197-1:2011. Cement- Part 1: Composition, specifications and conformity criteria for common cements. Brussels, Belgium, 2011.

[9] PROVIS, J. L.; van DEVENTER, J. S. J. (ed.) Alkali Activated Materials. State of the Art Report (Vol. 13). RILEM TC 224AAM. Springer. 2014. 388p.

[10] JUENGER, M.C.G.; WINNEFELD, F.; PROVIS, J.L.; IDEKER, J.H. Advances in alternative cementitious binders. Cement and Concrete Research 41 (2011) 1232-1243.

[11] SHI, C.; JIMÉNEZ, A. F.; PALOMO, A. New cements for the 21st century: The pursuit of an alternative to Portland cement, Cement and Concrete Research 41 (2011) 750-763.

[12] SILVA, M. G. (coordenador). Estrutura Hidráulica de Proteção Contra a Ação de Ondas Marinhas. Relatório Técnico, Núcleo de Excelência em Escórias Siderúrgicas (NEXES). Centro Tecnológico. Universidade Federal do Espírito Santo, 2006a.

[13] COELHO, M. A. M.; SILVA, M. G.; SOUZA, F. L. S.; SARMENTO, R.; ZANDONADE, E.; MORIMOTO, T.; HELMER, J. L. Bloco de concreto tipo quebra-mar com escória de alto-forno ativada quimicamente. Tecnologia em Metalurgia e Materiais (São Paulo. Impresso), 2009, v.5, p.186 - 191.

[14] INTERNATIONAL ORGANIZATION FOR STANDARDIZATION (ISO). ISO 14040: Environmental Management - Life cycle principles and Framework. Switzerland, 2006a.

[15] INTERNATIONAL ORGANIZATION FOR STANDARDIZATION (ISO). ISO 14044: Environmental Management - Life cycle assessment - Requirements and guidelines. Switzerland, 2006b.

[16] HABERT, G.; OUELLET-PLAMONDON, C. Recent update on the environmental impact of geopolymers. RILEM Technical Letters, 1:17-23, 2016.

[17] DAVIDOVITS, J. Environmental implications of Geopolymers. Materials Today Plus. 2015.

[18] HEATH, A.; PAINE, K., MCMANUS, M. Minimising the global warming potential of clay based geopolymers. J Cleaner Prod, 78: 75-83. 2014. 
[19] TURNER, L.K.; COLLINS, F.G. Carbon dioxide equivalent (CO2-e) emissions: A comparison between geopolymer and OPC cement concrete. Constr Build Mater (2013) 43: 125130.

[20] MCLELLAN, B.C.; WILLIAMS, R.P.; LAY, J.; VAN RIESSEN, A.; CORDER, G.D.. Costs and carbon emissions for geopolymer pastes in comparison to ordinary portland cement. J Cleaner Prod (2011) 19: 1080-1090.

[21] HABERT, G.; D'ESPINOSE DE LACAILLERIE, J.B., ROUSSEL, N. An environmental evaluation of geopolymer based concrete production: reviewing current research trends. Journal of Cleaner Production 19. 1229-1238, 2011.

[22] MENANDRO, F. C. M.; Silva, M. G. ; Souza, F. L. S. ; Sarmento, R. ; Zandonade, E. ; Morimoto, T.; Coelho, M. A. M. Resposta Estrutural do Bloco Hydrus para Estrutura Hidráulica para Proteção de Ondas Marinhas. In: VI Simpósio EPUSP sobre Estruturas de Concreto, 2006, São Paulo. Anais do VI Simpósio EPUSP sobre Estruturas de Concreto. São Paulo: EPUSP. v. 1. p. 1-10.

[23] DEPARTMENT OF THE ARMY, WATERWAYS EXPERIMENT STATION, CORPS OF ENGINEERS, COASTAL ENGINEERING RESEARCH CENTER. Shore protection manual, vol II. 4th ed. Vicksburg, Miss: 1984.

[26] GOEDKOOP, M.; SCHRYVER, A. D.; OELE, M. Introduction to LCA with SimaPro 7. Amersfoort: Product Ecology Consultants, 2008. $82 \mathrm{p}$.

[25] SAADE, M.; SILVA, M.; GOMES, V. Impact distribution in the steelmaking multifunctional process: a novel perspective on the avoided burden approach. In: Sustainable Built Environment Regional (SBE Zurich)_Expanding Boundaries: Systems Thinking for the Built Environment. Proceedings. Zurich, 2016c.

[26] SAADE, M. R. M., SILVA, M. G., GOMES, V. Appropriateness of environmental impact distribution methods to model blast furnace slag recycling in cement making. Resources, Conservation and Recycling, v.99, p.40 - 40, 2015.

[27] EUROPEAN COMMITTEE FOR STANDARDIZATION (CEN). Sustainability of construction works - Environmental product declarations - Core rules for the product category of construction products. EN 15804. Brussels: 2012.

[28] GUINÉE, J., GORRÉE, M.; HEIJUNGS, R.; HUPPES, G.; KLEIJN, R.; KONING, A. DE; OERS, L. VAN; WEGENER SLEESWIJK, A.; SUH, S.; UDO DE HAES, H.A.; BRUIJN, H. DE; DUIN, R. VAN; HUIJBREGTS, M.A.J. 2002. Handbook on life cycle assessment. Operational guide to the ISO standards. Part III: Scientific background. Kluwer Academic Publishers, ISBN 1-4020-0228-9, Dordrecht, 692 pp.

[29] HOEKSTRA, A. Y., CHAPAGAIN, A K., ALDAYA, M. M., MEKONEEN, M. M. Water footprint assessment manual - Setting the Global Standard. 2001 London, Earthscan.

[30] EUROPEAN UNION, 2008. (European Waste Framework) Directive 2008/98/EC of the European Parliament and the Council of 19 November 2008 on Waste and Repealing Certain Directives. Official Journal of the European Union, 22/11/2008.

[31] SAADE, M. R. M.; SILVA, M. G.; GOMES, V. O uso de distribuição de impactos em ACV's de processos multifuncionais: uma revisão sistemática da literatura publicada nos últimos 10 anos. V Congresso Brasileiro de Gestão do Ciclo de Vida. Anais. Fortaleza, CE. 2016bSA.

[32] PINTO, A.T. Sistemas Ligantes Obtidos por Activação Alcalina do Metacaulino. Tese Doutorado, Universidade do Minho, Portugal. 2004.

[33] WEIL, M.; DOMBROWSKI, K.; BUCHWALD, A. Life-cycle analysis of geopolymers. In: Provis JL, Deventer JSJv (ed.) Geopolymers: Structure, Processing, Properties and Industrial Applications. Woodhead Pub-lishing, 2009.

[34] SILVA, M. G. (coordenadora). Concreto de Alto Desempenho com Elevados Teores de Escória de Alto Forno: Estratégia para consolidar o Mercado da Escória de Alto Forno. Relatório Técnico, Núcleo de Excelência em Escórias Siderúrgicas (NEXES). Centro Tecnológico. Universidade Federal do Espírito Santo, 2006b. 